3. Brown, H. C. Value and Potentiality. J. of Phil., Psychol, etc., 1914, 11, 29-37.

4. Conen, M. R. History versus Value. J. of Phil., Psychol., etc., 1914, 11, 701-716.

5. Croce, B. Philosophy of the Practical. New York: Macmillan, 1913. Pp. xxiv $+59 \mathbf{I}$.

6. Delaguna, T. Introduction to the Science of Ethics. New York: Macmillan, r9r4. Pp. vi +411 .

7. Frsuer, D. W. The Problem of the Value-Judgment. Phil. Reo., 1913, 22, 623638.

8. Hazking, T. Untersuchungen zur Psychologie der Wertung (auf experimenteller Grundlage). Arch. f d. ges. Psychol, 1913, 26, 269-360; 27. 63-194, 285-366.

9. Honson, H. A. Work and Wealth: A Human Valuation. New York: Macmillan, 1914. Pp. xvi +367 .

10. Kallen, H.M. Value and Existence in Art and in Religion. J. of Phil., Psychol., etc., 1914, $11,264-276$.

11. Lessing, T. Studien zur Wertaxiomatak, Untersuchungen uber reine Ethik und rrites Recht. Ieipzig: Meiner, 1914. Pp, xix +121.

12. Liebert, $\Lambda$. Das Problem der Geltung. Kantstud., 1914, 19 (Ergh. 32). Pp. 262.

13. Moore, J. S. The System of Transcendental Values J. of Phil., Psychol., etc., $1914,11,244^{-24} 8$.

14. Moor E, J. S. Montague's Classification of Values. J. of Phil., Psychol., etc, $1914,11,352-355$.

15. Perry, R B. The Definition of Value. J. of Phtl., Psychol., etc., 1914, 11, 14I162.

16. Rinot, T. Ree. Phil., 1914, 144-16r.

17. Rickert, H. Vom System der Werte. Logof, 1913, 4, 295-327

18. SCHELER, M. Der Formalismus in der Ethik und die materielle Wertethik Jahrb. f. Phil. u. phanom. Forschung, 1913.

19. Sheldon, W. H. An Empirical Definition of Value. Reo. of Phil., Psychol., etc., $1914,11,113-124$.

20. TAlbot, E. B. The Time Process and the Value of Human Life. Phil. Reo., 1914, $23,634-647 ; 24,17-36$.

\title{
PSYCHOLOGY OF TESTIMONY
}

BY GUY MONTROSE WHIPPLE

The Unioersity of Illinois

Contributions to the psychology of testimony during the past year have been rather more interesting and ingenious, though less numerous, than during recent years. Take, for example, the work of Benussi (I), at the psychological laboratory of Graz, who used a Marey pneumograph to trace curves of respiration while his subjects read off or described the contents of small cards (letters, digits, drawings). On half of the cards, taken in chance order, was a symbol meaning "lie," whereupon the subject had deliberately to 
falsify his statements concerning the contents of the card. A "jury" of a dozen or more auditors judged each Aussage as "lying" or "telling truth." The net results were: (I) The human jury, taken on the average, made little better than a "chance shot" (about 55 per cent. right cases); (2) the mechanical jury (pneumograph) was practically infallible (nearly 100 per cent. right cases); (3) it also distinguished between good and poor dissimulators; (4) false statements made with full knowledge that the auditors knew their falsity leave the same records as truthful statements, so that the emotional status of the liar is the essential element in his detection; (5) attempts of the subject to modify breathing do not destroy the significant feature of the respiratory tracing which consists in this; that the ratio between length of inspiration and length of respiration is in lying greater after than before the statement, and in truth-telling greater before than after the statement.

Hélène Lelesz (7) showed two pictures to 124 persons of both sexes, aged 10 years up, and secured a narrative and deposition after the usual Bild-Fersuch method. Her data were then subjected to the usual formulas to compute range, spontaneity, fidelity and other coefficients of report, but with the added feature that each subject was catalogued according to his intellectual type (as judged by his report). Five types were discovered: (1) the descriptive, (2) the superficial, (3) the intelligent, (4) the interpretive and (5) the ambitious. The meaning of these terms is fairly obvious. The superficial type reports only the outward aspects of the picture, is found in 27 per cent. of the subjects, and is three times as common in children as in adults. The interpretive (subjective) type, resembling Binet's imaginative or poetic, is found in 24 per cent. of the subjects, the descriptive in 10 per cent., the intelligent in 30 per cent. and the ambitious in but 3 per cent. This last is like Binet's erudite type, plus a touch of pretence and showingoff. The author believes that a knowledge of the type to which a witness belonged would enable a judge to appraise in advance the probable reliability of his testimony. Her own qualitative evaluation assigns, in arbitrary units, the values: intelligent 300 , descriptive 262 , interpretive 208 , superficial $\mathbf{1} 60$.

Feingold (4) experimented upon the recognition (identification) of picture post cards when displayed in a setting of other cards. It was shown that the degree of recognibility is inversely related to degree of similarity. The experiments were then directed toward the question whether identification would be easier if the object 
were in its old setting or in a new setting, and the ultimate conclusion reached is that identification is facilitated by maintaining the original setting, while little danger exists of making false identifications on account of using an old setting. The bearing of the experiments upon testimony involving identification of suspected characters is obvious enough.

Boden (2) employed a new form of testimony experiment, which he regards as more useful than the picture test. The subjectmatter was a prearranged dialogue concerning a business transaction (like sub-letting a house or contracting for the retail handling of an article of commerce). The auditors wrote at once an account of the conversation as they had understood it. There was (unfortunately, it seems to me) no time-interval and no interrogatory. The chief conclusion is that witnesses do very well with such material (better than with the picture test, because of the more realistic, and also more abstract character of the material), yet fail when the presented material is obscure (here intentionally) in that they do not report the obscurity, but unwittingly take sides and color their reports. In a doubtful issue they appear to take sides about evenly. Of course, it is just these obscure points that are often most important legally.

Kobler (6), at a meeting of a legal society at Vienna, carried out cleverly a prearranged scene which included interruptions of a colleague's address and a caustic exchange of remarks, verging on insults and threats. Everything was done to secure realism. Several weeks later actions were brought before two tribunalsone of three laymen versed in psychology, who were to regulate the proceedings as they saw fit, the other of three professional judges, who were to follow legal forms strictly. Each tribunal was to examine the same witnesses and to arrive at a finding as to the facts of the original scene, to render a verdict and to determine damages. The two courts reached rather similar results; their findings were condensed, simplified and somewhat distorted in comparison with the actual occurrence. Analysis of the testimony confirms previous conclusions that excitement improves observation and memory of witnesses up to a given point (variable for different persons) and impairs it beyond that point. Dauber's demonstration that agreement of witnesses may mean agreement of erroneous testimony is again confirmed.

Kati Lotz (8) lost her umbrella and concocted an article on the fallibility of human testimony from her experiences in recovering it. 
Stress is laid particularly upon the point that here were witnesses without the slightest intent to deceive, that they would have impressed any court as being absolutely impartial and unprejudiced, but that, nevertheless, they were "prejudiced" by their previous knowledge of her habits with respect to umbrellas. The moral is that in reporting a seemingly isolated item about a well-known person, one's account is unconsciously colored to accord with one's general knowledge of the person.

Du Bois (3) discusses in a rambling manner the position of the juror. His general contention is that the juror is asked to perform a delicate bit of work that should demand optimal conditions for passing judgment, but is harrassed and bandied about and generally irritated by conditions of jury duty until his whole mental attitude is out of joint.

Friedrich (5) publishes the prospectus of a sort of continuation course for jurists and public officials in conjunction with courses in political economy and allied lines held at the Cologne Hochschule in 1914-15. The plan calls, among other things, for lectures, discussions and experiments upon the psychology of court officials, the psychology of testimony, the worth of children's testimony, etc. As a plan to acquaint legal authorities with what men of science are trying to do in the fields of criminology and applied psychology, this surely deserves the attention of some of us on this side the water.

\section{REFERENCES}

1. Benusst, $V$. Die Atmungssymptome der Lige. Atch. f.d.ges. Psychol, 1914, 31, $244^{-273}$.

2. Boden, - Ein zivilprozessualer Aussageversuch. Arch. f. d. ges. Psychol., 1914, $32,257-280$.

3. DuBois, P. Some Observations on the Psychology of Jurors and Juries. Proc. Amer. Phil. Soc., 1914, 33, 307-322.

4. Feimgold, G. A. The Influence of Environment on Identification of Persons and Things. J. of Crim. Law and Criminol., 1914, 5, 39-51.

5. Friedrich, J. Ein neuer Weg zur Fortbildung der Juristen. Zsch. f. angew. Psychol., t914, 8, 370-373.

6. Koвter. Ein rechtspsychologisches Experiment. Zsch. f. angew. Psychol., 1914, 8, 317-325.

7. Lelesz, H. L'orientation d'esprit dans le Témoignage. Arch. de psychol., 1914, 14, $113-157$.

8. Lotz, K. Zur Aussagepsychologie. Zsch. f. angew. Psychol., 1915. 9. 515-518. 